also thank Allan Hackshaw, Tuan Nguyen, and Deborah Hart for statistical support.

1 Lawrence JS. Disc degeneration: its frequency and relationship to symptoms. Ann Rheum Dis 1969;28:121-38.

2 Orwoll ES, Oviatt SK, Mann T. The impact of osteophytic and vascula calcifications on vertebral mineral density measurements in men. $\mathcal{f}$ Clin Endocrinol Metab 1990;70:1202-7.
3 Reid IR, Evans MC, Ames R, Wattie DJ. The influence of osteophytes and aortic calcification on spinal mineral density in postmenopausal women. f Clin Endocrinol Metab 1992;72:1372-4.

4 Dawson-Hughes B, Dallal GE. Effect of radiographic abnormalities on rate of bone loss from the spine. Calcif Tissue Int 1990;46:280-1.

5 Dequeker J. The relationship between osteoporosis and osteoarthritis Clin Rheum Dis 1985;11:271-95.

(Accepted 13 May 1993)

\section{Late cardiac manifestation of infection with Borrelia burgdorferi (Lyme disease)}

\author{
Johnny Vegsundvåg, Jan Nordeide, \\ Åsmund Reikvam, Pål Jenum
}

Department of medicine, cardiology section, Central Hospital of Sogn and Fjordane, N-6800 Førde, Norway

Johnny Vegsundvåg, registrar

Åsmund Reikvam, consultant

\section{Department of rheumatology, Central Hospital of Sogn and Fjordane} Jan Nordeide, consultant

Department of bacteriology, National Institute of Public Health, N-0462 Oslo, Norway Pål Jenum, consultant

Correspondence to: Dr Vegsundvåg.

$B M F$ 1993;307:173 reported before.

\section{Case report} bacterial treatment.
The whole range of cardiac complications of Lyme disease, which is caused by the tick borne spirochaete Borrelia burgdorferi, is not yet clear. We report a case of a very late debut of Lyme carditis, which has not been

A female patient, born in 1923, lived in a rural area of western Norway, where Lyme disease is endemic. In the summer of 1972 she developed a rash typical of erythema migrans on her right flank. She did not recall any tick bite. The lesion disappeared after some weeks. Thereafter she developed a transient burning pain on the right side of the body and a transient right sided Bell's palsy followed by a contralateral Bell's palsy. Afterwards she constantly had migratory myalgias, arthralgias, and malaise consistent with chronic borrelia infection. She was not given anti-

In the spring of 1990 she developed a persistent stabbing pain centrally in the chest, burning sensations on the right side of the body, an increasing exertional dyspnoea, feelings of cold, and a growing malaise. On admission to hospital early in June 1990, she had dyspnoea with moderate exertion. Clinical examination revealed a sequela on the left side after Bell's palsy. Her erythrocyte sedimentation rate was $80 \mathrm{~mm} / \mathrm{h}$. Serum protein electrophoresis showed a transient acute phase response. Tests for cryoglobulins, circulatory immune complexes, syphilis, leptospirosis, cytomegalovirus, coxsackievirus B, autoantibodies, and antibodies against cardiolipin were all negative. Serological analysis gave no indication of recent infection with streptococcus or Epstein-Barr virus. Haematological and biochemical values were either normal or without actual significance.

Electrocardiograms showed initially fluctuating diffuse $\mathrm{T}$ wave inversions. Radionuclide ventriculography revealed a left ventricular ejection fraction of $55 \%$. Echocardiography showed little pericardial effusion and increased left ventricular dimensions. A chest roentgenogram showed considerable cardiomegaly and slightly distended pulmonary veins whereas previous chest roentgenograms, the latest taken in 1987, had been normal.

The table shows the results of different assays for borrelia antibodies in cerebrospinal fluid and serum samples. The specific antibody ratio index was calculated from tests for borrelia antibodies by indirect haemagglutination. ${ }^{1}$ This index reflects the relative specific antibody load in cerebrospinal fluid compared to that of serum. The calculated index of 42.5 was high,
Results of tests for borrelia antibodies on cerebrospinal fluid and serum samples taken from a patient at different times

\begin{tabular}{|c|c|c|c|c|}
\hline & \multicolumn{4}{|c|}{ Time when sample collected } \\
\hline & \multicolumn{2}{|c|}{ June 1990} & \multirow[b]{2}{*}{$\begin{array}{r}\text {-October } \\
1990 \\
\text { serum }\end{array}$} & \multirow[b]{2}{*}{$\begin{array}{c}\text { Decembe } \\
1991 \\
\text { serum }\end{array}$} \\
\hline & $\begin{array}{l}\text { Spinal } \\
\text { fluid }\end{array}$ & Serum & & \\
\hline $\begin{array}{l}\text { Indirect haemagglutination } \\
(\text { titre })^{\star}\end{array}$ & 40 & 400 & 400 & $<200$ \\
\hline Specific antibody ratio index & \multicolumn{2}{|c|}{$42 \cdot 5^{400}$} & & \\
\hline \multicolumn{5}{|l|}{ Enzyme immunoassays (\%):† } \\
\hline \multicolumn{2}{|l|}{ Borrelia flagella } & & 669 & 475 \\
\hline IgM & & $<100$ & $<100$ & $<100$ \\
\hline \multicolumn{5}{|l|}{ Sonicated Borrelia $\uparrow$} \\
\hline $\mathrm{IgG}$ & \multicolumn{4}{|c|}{$<100$} \\
\hline IgM & \multirow{2}{*}{\multicolumn{4}{|c|}{$<100$}} \\
\hline Total immunoglobulin\| & & & & \\
\hline Western blotting & \multirow{2}{*}{\multicolumn{4}{|c|}{ Positive $\star \star$}} \\
\hline $\mathrm{IgG}$ & & & & \\
\hline IgM & \multicolumn{4}{|c|}{ Negative } \\
\hline
\end{tabular}

${ }^{\star}$ Lymag, Diagast Laboratoires, Lille, France.

†Results related to cut off $(100 \%)$ so that values $>100$ are positive, $<100$ are negative.

$\ddagger$ Lyme borreliosis ELISA kit, Dako, Glostrup, Denmark

$§$ Test based on sonicated whole cells of $B$ burgdorferi.

Human Lyme EIA diagnostic test, Cambridge BioScience, Worcester, USA.

ICambridge BioScience, Worcester, USA

$\star \star$ Borrelia protein antigens of $41,21,56$, and $75 \mathrm{kDa}$ showed reactivity.

indicating intrathecal production of borrelia antibodies and therefore past or present neuroborreliosis.

From the middle of June the patient was treated intravenously with $3 \mathrm{~g}$ benzylpenicillin three times daily for three weeks. During treatment her symptoms rapidly faded, and she felt well for the first time since her erythema migrans in 1972 . Her erythrocyte sedimentation rate had fallen to $12 \mathrm{~mm} / \mathrm{h}$ in August 1990 , and her echocardiogram and chest roentgenogram were unremarkable. She was still well two years after the antibiotic treatment.

Comment

The typical medical history, positive assays for borrelia antibodies, and quick and lasting response to adequate antibiotic treatment form the basis for the diagnosis of Lyme carditis in the patient, which appeared 17-18 years after the primary infection. The patient received no treatment except benzylpenicillin which could have contributed to the remission. The medical history and laboratory findings gave no indication of any other disease that could explain the cardiac manifestations. A recent retrospective study of patients with dilating cardiomyopathy suggests that this condition could be a late manifestation of Lyme borreliosis. ${ }^{2}$ If this is correct our patient could have been in an early phase of a progressive dilating cardiomyopathy. Antibiotic treatment was effective in this case, which suggests that such treatment at an early stage of an assumed progressive dilating cardiomyopathy may halt or cure the condition.

\footnotetext{
1 Hofstad H. Serologisk diagnostikk av Borrelia burgdorferi infeksjon. Tidsskr Nor Legeforen 1987:107:3038-40.

2 Stanek G, Klein J, Bittner R, Glogar D. Borrelia burgdorferi as an etiologic agent in chronic heart failure? Scand f Infect Dis 1991;77:85-7.
}

(Accepted 19 April 1993) 